\title{
Biogas Production from Palm Oil Fruit Bunch in Anaerobic Biodigester through Liquid State (LS-AD) and Solid State (SS- AD) Method
}

\author{
Bakti Jos ${ }^{1, *}$, Hanif Farhan ${ }^{1}$, Nadia Dwi Ayu ${ }^{1}$, Budiyono $^{1}$, and Siswo Sumardiono ${ }^{1}$ \\ ${ }^{1}$ Department of Chemical Engineering, Faculty of Engineering, Diponegoro University, Jl.Prof. Soedarto, SH, Tembalang, Semarang, \\ Indonesia 50275
}

\begin{abstract}
The crucial problem facing the world today is energy resources. Waste production of palm oil fruit bunch potentially produce as renewable energy resource. Palm oil fruit bunch contains $44 \%$ cellulose, $18 \%$ lignin and $34 \%$ hemicellulose. Organic carbon source is contained in biomass potentially produce biogas. Biogas is one of alternative energy, which is environmentally friendly and has been widely developed. This research is aimed to examine the effect of pretreatment in raw material of waste palm oil fruit bunch for the production of biogas, the effect of time, ratio $\mathrm{C} / \mathrm{N}$, and effect of microbial consortium. The variables are total solid (TS) used $10 \%$ and $18 \%$ with a 40 mesh physical pretreatment, chemical pretreatment with $\mathrm{NaOH} 8 \%$ gr / gr TS, and biology 5\% g/vol with microbial consortium. Biogas production process was conducted over 2 months in room temperature, the test response quantitative results in the form of biogas volume every 2 days and also flame test. The result of this research shows that the highest daily production rate of biogas obtained from this study was $5,73 \mathrm{ml} / \mathrm{gr}$ TS and the highest biogas production accumulation generated at $58,28 \mathrm{ml} / \mathrm{gr}$ TS produced through a 40 mesh sieve of waste oil palm empty fruit bunch, immersion in $\mathrm{NaOH}$, through solid state fermentation and $\mathrm{C} / \mathrm{N} 30$. From this research, it can be concluded that the optimum production of biogas formation occurs with the value of $\mathrm{C} / \mathrm{N} 30$, physical and biological pretreatment, and solid state method.
\end{abstract}

\section{Introduction}

World energy demand is expected to increase rapidly along with population growth and economic development. Dependency on fossil energy particularly fossil fuel, to fulfill high energy consumed of the country, which is $96 \%$ (48\% crude oil, $18 \%$ gas, and $30 \%$ coal) of total consumption and to optimize renewable energy utilization [1]. Energy consumption is increased continuously due to population growth [2]. Total fuel consumption for energy production is being increased every year, in the last 5 years, fuel oil consumed increase $18 \%$ until 2013 its consumption increase by 197,4 thousand $\mathrm{kl} / \mathrm{d}$ and total fuel consumption in 2014 is 308 million equal to barrel oil or decrease $0.18 \%$ per year.

In order to overcome the increasing of energy demands, renewable energy has remained one of the best alternatives for sustainable energy development [3]. Energy consumption has an effect on economic growth and national defense. One of renewable energy sources which is being pursued for its development nowadays is bioenergy. Bioenergy or biofuel is energy from organic matter (biomass) [4]. Biofuels can be divided into bioethanol, biodiesel and biogas [5]. Biogas is one of alternative energy, which is environmentally friendly and has been widely developed [6]. Biogas can be categorized as bioenergy, because the energy produced from biomass [7].

Biogas production is carried out by microbes in anaerobic condition as known Anaerobic Digestion (AD) process or fermentation from organic matters or biomass $[8,9]$, for instance agricultural waste, organic waste, animal or human manure, industrial waste and domestic waste in anaerobic condition [10-12]. In anaerobic digestion, organic materials will be converted by bacteria into the biogas through four major phases i.e. hydrolysis, acidogenesis, acetogenesis and methanoogenesis [1315]. In the hydrolysis phase, complex organics (carbohydrate, protein, fat) are converted into simple organics (sugar, amino acid, LVFA); in the acidogenesis phase, simple organics are converted into organic acids ; for the acetogenesis phase, organic acids are converted into acetic acid, and the final phase is methanoogenesis that aim for converting acetic acid into $\mathrm{CH} 4$ and $\mathrm{CO} 2$ [16] Biogas is a renewable energy with a composition consisting of $50-75 \%$ methane (CH4), 34-45\% carbon dioxide (CO2) and other gases in small amounts such as $\mathrm{CO}, \mathrm{N}_{2}, \mathrm{H}_{2}, \mathrm{H}_{2} \mathrm{~S}$, and $\mathrm{O}_{2}$ [17].

The anaerobic digestion (AD) process is generally classified into two categories based on the total solid (TS) content of the mixture in the digester [18]. TS contents of $15 \%$ or greater are classified as solid state anaerobic digestion (SS-AD) while TS contents of 15\% or lower are classified as liquid anaerobic digestion (LS- 
AD) [19]. Biogas has $20 \%$ lower weight than air and has heat of combustion value between $4800-6200 \mathrm{kcal} / \mathrm{m}^{3}$. Its value is lower than methane heating value reach 8900 $\mathrm{kcal} / \mathrm{m}^{3}$ [20]. Biogas can be produced through appropriate technology which is relatively simpler [21], so it can be applied either in town or village. According to the Ministry of Energy and Mineral Resources, biogas has applied in both developed and developing countries.

First generation biogas started from 1884, Pasteur attempted to produce biogas from cattle [22]. Biogas is also often produced from other livestock waste such as chicken waste, pig waste, and horse waste. Biogas has developed rapidly until the second generation of biogas [23]. Second generation of biogas can be produced from lignocelluloses material such as agricultural or forestry waste for instance include straw, waste plant corn, palm oil fruit bunch, bagasse, grass, wood and many more [24]. Palm oil fruit bunch is one with huge potential to be developed in Indonesia. Palm oil fruit bunch is waste residue generated from palm oil industries. This country is the world's largest producer and exporter of palm oil and expected to be continuously increased.

According to Directorate General of Plantations, Ministry of Agriculture Indonesia, the average of palm oil area growth rate from $2004-2014$ reached $7.67 \%$ and palm oil production increases to an average of 11,09 $\%$ per year. Palm oil fruit bunch is one of the solid wastes produced in huge volume by palm oil mill, however, it was not fully utilized till then, and therefore it needs to be followed for the extensive utilization of waste palm oil fruit bunch. One of these is to convert waste palm oil fruit bunch into biogas as an alternative energy [25].

Palm oil fruit bunch contains $40-60 \%$ cellulose, 20 $30 \%$ hemicellulose, and 15-30 \% lignin [26]. Lignocellulose content within palm oil fruit bunch can be converted into biogas, however, lignocellulose biomass has a complex internal structure, thus it needs aggressive pretreatment to yield a substrate easily hydrolyzed by cellulolytic enzymes or enzyme producing microorganisms [27].

Pretreatment of raw material lignocellulose in order to improve the yield of the biogas produced can be done by chemistry, physics, and biology pretreatment [2830]. Therefore, to achieve increased biogas yield higher, require further study regarding pretreatment method more effective. This research will use a combination pretreatment method that consists of physical, chemical and biological pretreatment. Physical pretreatment is used to disrupt cellulose crystallinity, reduce particle size, and increase the surface area [31], it can be done by milling or grinding the raw material [27]. Afterward, the process followed by adding $\mathrm{NaOH}$ for chemical pretreatment, it refers to enhance the biodegradability of cellulose and lignin removal [31].

The final step of this combination pretreatment is biological pretreatment. Biological pretreatment is carried out by microorganisms such as microbial consortium, which mainly degrade lignin, also reduce polymerization degree and crystallinity of cellulose [29]. Thus, pretreatment combination method is expected to increase biogas yield in anaerobic digestion. This research is also aimed to observe the comparison of methane yield in liquid state anaerobic digestion (LS- AD) and solid state anaerobic digestion (SS-AD).

\section{Materials and Method}

\subsection{Materials}

Materials used in this study are the palm oil fruit bunch, cow rumen obtained, microbial consortium, $\mathrm{NaOH}$, urea, water, and $\mathrm{HCl}$.

\subsection{Preparation Stage}

At this stage, the samples of farm waste such as palm oil fruit bunch from Banten, cow rumen is taken from the slaughterhouse in Semarang, microbial consortium from Banyuwangi. Besides, $\mathrm{NaOH}$ as lignocellulose degradation agent and $\mathrm{HCl}$ are bought in Indrasari chemicals store, Semarang. After that, the palm oil fruit bunch as much as 220 grams (for liquid state variables) and 360 grams (for solid state variables) are reduced according to 40 mesh. Then the raw materials are added with $8 \%$ gr/gr TS of $\mathrm{NaOH}$ and the $\mathrm{pH}$ is set by using $\mathrm{HCl}$ for maintaining a close to neutral $\mathrm{pH}$. For biological pretreatment is used 5\% $\mathrm{v} / \mathrm{v}$ microbial consortium to be processed at a further stage.

\subsection{Operation Methods}

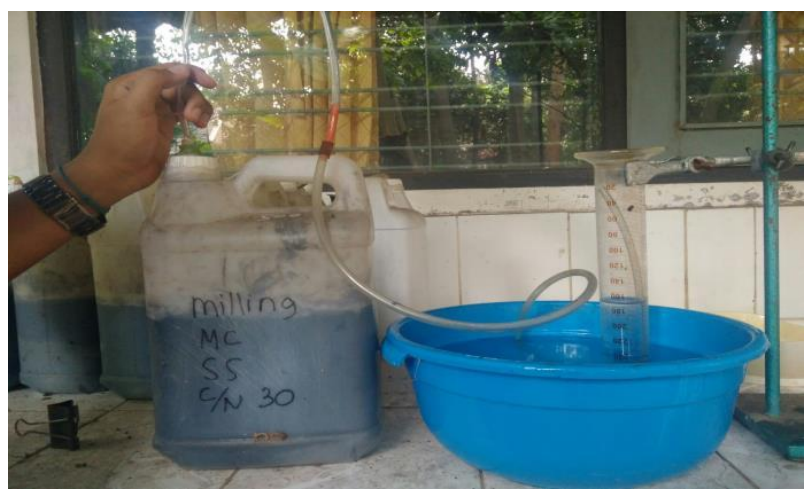

Fig. 1 The Apparatus of biogas production

Substrates that have been homogeneously are mixed with cow rumen as much as 110 grams (for liquid statevariables, $10 \%$ total solid) and 220 grams (for solid state variables, $18 \%$ total solid) as starter of methanogen microbes. After that, the urea is added as micronutrients as much as 3.92 grams for c/n 25 and 2.65 grams for $\mathrm{c} / \mathrm{n} 30$ and water is also added until 2000 $\mathrm{ml}$. the fermentation process is started. The volume of gas hat is formed is measured by water displacement technique every other day for 62 days, as shown in fig 1 .

\subsection{Results Analysis Stage}

The data of biogas volume is analyzed in graphical form as relationship biogas volume versus time. 


\section{Results and Discussion}

\subsection{The Effect of Palm Oil Fruit Bunch Size on Physical Pretreatment against Biogas Production}

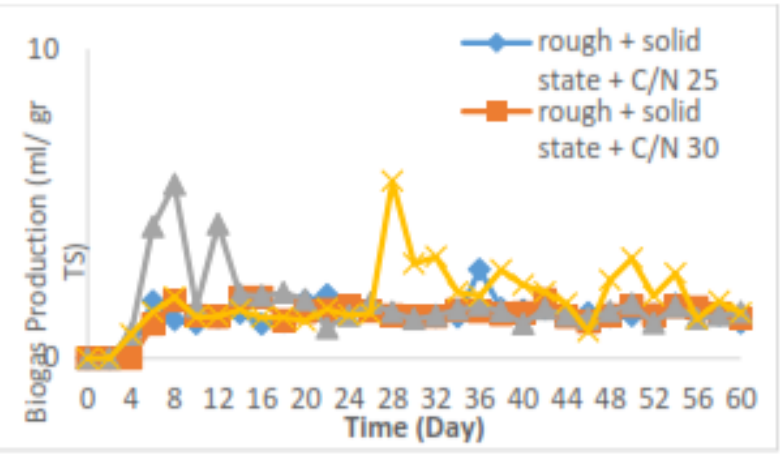

Fig. 2. The rate of the daily biogas production from palm oil fruit bunch in solid state condition with $\mathrm{c} / \mathrm{n} 25$ and 30

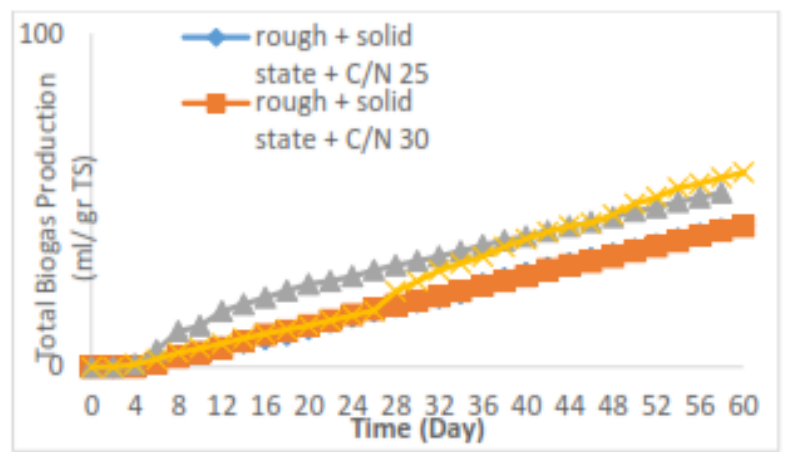

Fig. 3. The total biogas production from palm oil fruit bunch in solid state condition with $\mathrm{c} / \mathrm{n} 25$ and 30

Figures 2 and 3 show a comparison of the biogas production of palm oil fruit bunch through size reduction 40 mesh and without being reduced. Total production of biogas in smooth palm oil fruit bunch $\mathrm{C} / \mathrm{N} 25$, smooth $\mathrm{C} / \mathrm{N} 30$, rough $\mathrm{C} / \mathrm{N} 25$ and rough $\mathrm{C} / \mathrm{N} 30$ consecutive reaching $53.47 \mathrm{ml} / \mathrm{gr}$ TS, $58.28 \mathrm{ml} / \mathrm{gr} \mathrm{TS}, 42.43 \mathrm{ml} / \mathrm{gr}$ TS, $42.15 \mathrm{ml} / \mathrm{gr}$ TS. The highest total volume of biogas produced in delicate palm oil fruit bunch $\mathrm{C} / \mathrm{N} 30$, in the amount $58.83 \mathrm{ml} / \mathrm{gr}$.

Biogas production on a palm oil fruit bunch through size reduction process has the higher volume than biogas production in palm oil fruit bunch without being reduced. This is due to the particle size reduction that can reduce the crystallinity of cellulose and lignin defense disorders [32]. Thus, it will facilitate the process of hydrolysis resulting in an increased production of bioenergy [33]. In addition, size reduction for palm oil fruit bunch increases the surface area and reduces the degree of polymerization for cellulose [29]. So that, the smaller size of lignocelluloses substrate in this case is palm oil fruit bunch, the higher the production of biogas produced by the crystalline structure due to the increasing number of palm oil fruit bunch degraded to simplify the process of hydrolysis.

The addition of $8 \% \mathrm{NaOH}$ can help the destruction process of lignin structure, or commonly called delignification. Delignification process can destroy lignin structure and release carbohydrate compound [34]. Delignification process is a method to convert lignocellulose into glucose compound [35]. Delignification is believed as a potential process in preparation method of raw materials [29].

\subsection{The Effect of Microbial Consortium Addition against Biogas Production}

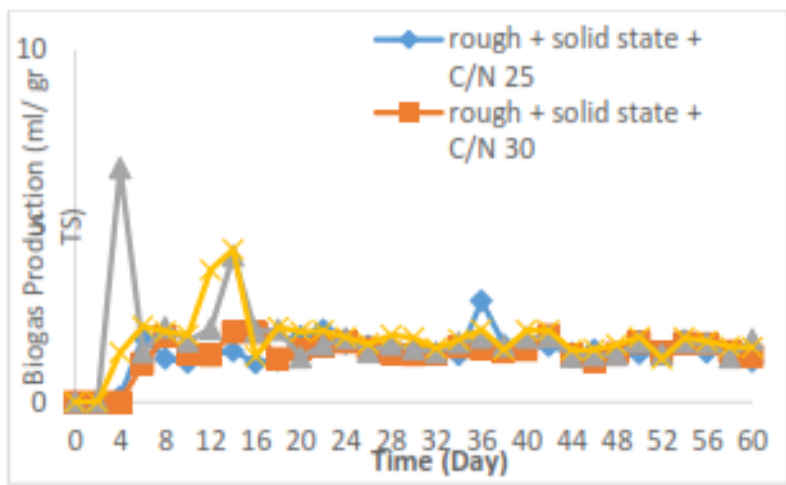

Fig. 4. Daily biogas production rate of palm oil fruit bunch in solid state condition with a C/N 25 and 30

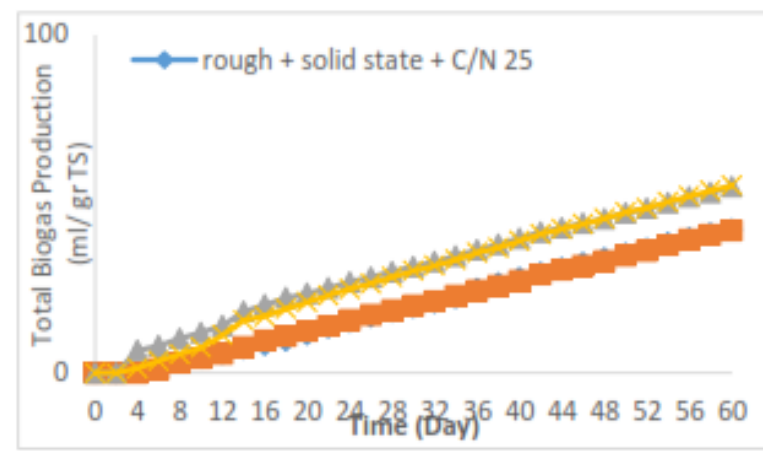

Fig. 5. Total biogas production rate of palm oil fruit bunch in solid state condition with a $\mathrm{C} / \mathrm{N} 25$ and 30

From Figure 4 and 5, it can be referred the comparison between biogas production from palm oil fruit bunch in solid state condition with the addition of $\mathrm{NaOH}$ at a ratio of $\mathrm{C} / \mathrm{N}$ of 25 and 30 with the addition of microbial consortium and without microbial consortium. Total production of biogas in the $\mathrm{C} / \mathrm{N} 25$ either by the addition of microbial consortium and without microbial consortium respectively for rough palm oil fruit bunch reached $55.11 \mathrm{ml} / \mathrm{gr}$ TS and $42.42 \mathrm{ml} / \mathrm{gr}$. While total production of biogas in the $\mathrm{C} / \mathrm{N} 30$ either by the addition of microbial consortium and without microbial consortium respectively for rough palm oil fruit bunch reached $55.43 \mathrm{ml} / \mathrm{gr}$ TS and 42,15 $\mathrm{ml} / \mathrm{gr}$ TS. The highest total biogas production on palm oil fruit bunch $\mathrm{C} / \mathrm{N} 30$ with the addition of microbial consortium, in the amount $55.43 \mathrm{ml} / \mathrm{gr}$ TS.

Biogas production on palm oil fruit bunch with the addition of microbial consortium has the higher volume than without the addition of microbial consortium. The 
activity of microbial consortium, which consisted by Streptomyces sp., Geobacillus sp., and Trichoderma fungi can enhance the delignification, decrease cellulose polymerization degree, and hydrolysis of hemicellulose. The addition of microbial consortium can change component structure and increase enzymatic hydrolysis, it can also relieve the hydrolysis process of cellulose into glucose [36, 37].

\subsection{Influence of $\mathrm{C} / \mathrm{N}$ and Biodigester Condition against Biogas Production}

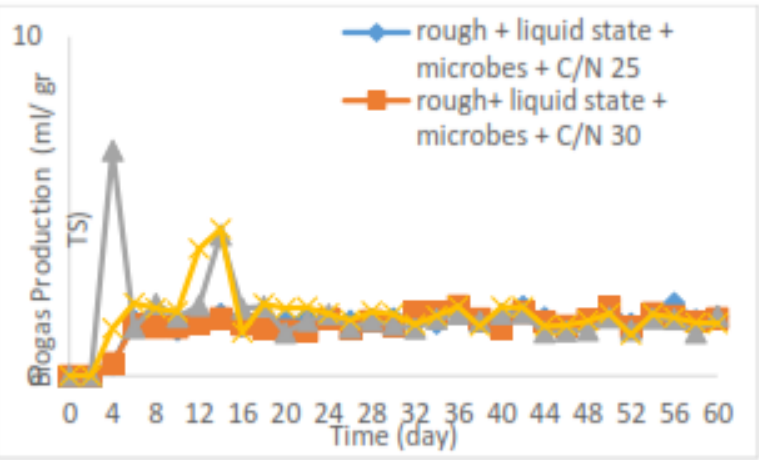

Fig. 6 Daily biogas production rate of palm oil fruit bunch in liquid state condition with a $\mathrm{C} / \mathrm{N} 25$ and 30

In the figure 6 and 7 can be seen a comparison of the production of biogas from palm oil fruit bunch in different condition of biodigester (Solid State and Liquid State) with the addition of $\mathrm{NaOH}$ and microbes, with differences in $\mathrm{C} / \mathrm{N}$, which serves as $\mathrm{C} / \mathrm{N} 25, \mathrm{C} / \mathrm{N} 30$. Total production of biogas in the liquid state $\mathrm{C} / \mathrm{N} 25$, liquid state $\mathrm{C} / \mathrm{N} 30$, solid state $\mathrm{C} / \mathrm{N} 25$ and solid state $\mathrm{C} / \mathrm{N} 30$ respectively for palm oil fruit bunch reached $47.28 \mathrm{ml} / \mathrm{gr}$ TS, $45.65 \mathrm{ml} / \mathrm{gr}$ TS, $55.11 \mathrm{ml} / \mathrm{gr}$ TS, 55.43 $\mathrm{ml} / \mathrm{gr} \mathrm{TS}$. The amount of $\mathrm{C} / \mathrm{N} 25$ both liquid state and liquid state have the higher volume than $\mathrm{C} / \mathrm{N} 30$, and also for solid state conditions reached the higher volume than liquid state conditions. The highest amount of biogas production on palm oil fruit bunch $\mathrm{C} / \mathrm{N} 30$ in solid state biodigester condition, amounting $55.43 \mathrm{ml} / \mathrm{gr}$ TS.

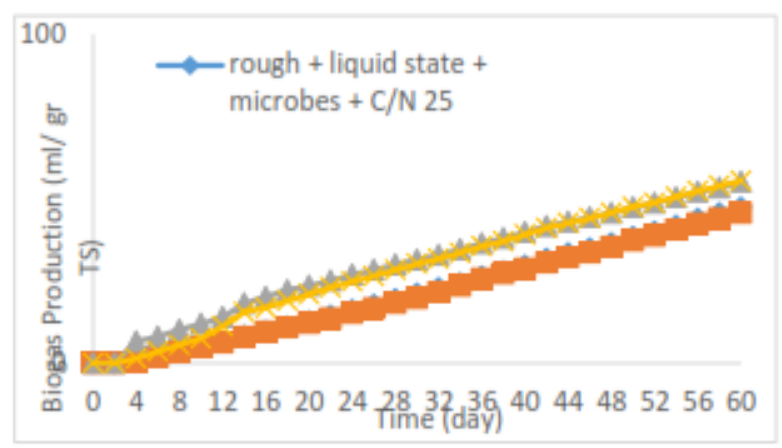

Fig. 7 Total biogas production rate of palm oil fruit bunch in liquid state condition with a $\mathrm{C} / \mathrm{N} 25$ and 30

$\mathrm{C} / \mathrm{N}$ from organic matters greatly influenced microbial activity and biogas production [24,38]. Microbes that play a role in the anaerobic processes require nutrients to grow and develop, in the form of a carbon source and a nitrogen source [39]. Equilibration of carbon and nitrogen in materials used as substrates also requires attention. Therefore, excessive nitrogen concentration can limit bacterial growth, in this case for the material that has very high ammonia contents [40], while the substrate that has slight nitrogen content, the bacteria will not be able to produce the enzyme which is needed to synthesize its compound (substrate) that contains carbon. The optimum production of biogas refers to $\mathrm{C} / \mathrm{N} 30$ because the most optimum substrate contains $\mathrm{C} / \mathrm{N}$ ranges from 20: 1 to 30: 1 [41].

Solid State Fermentation (SSF) holds high productivity level due to the nutrient content per volume that can be much more concentrated. Thus, it results the higher volume of biogas production [42-43].

\subsection{The Kinetic of Biogas Production Reaction}

By Assuming that the rate of biogas production in batch biodigester is proportional to the specific growth rate of methanogenic microorganisms in biodigester, the rate of biogas production will follow the Gompertz Equation [44]. Originally, Gompertz equation was used to predict bacterial growth rate. Currently, many authors used modified Gompertz equation to predict biogas production rate with assume that biogas production rate had correspondence to methanogenic bacteria growth rate in digesters [45]. This equation is a mathematical model for an observation time series, which is the slowest growth at the beginning and end of the period of observation time and have the general form as follows:

$$
y=A \exp \left\{-\exp \left[\frac{\mathrm{Ue}}{\mathrm{A}}(\lambda-1)+1\right]\right\}
$$

$\mathrm{y}=$ the cumulative production of biogas, $\mathrm{L} / \mathrm{kg}$ of " $\mathrm{t}$ " time.

$\mathrm{A}=$ the maximum production of biogas, $\mathrm{L} / \mathrm{kg}$

$\mathrm{U}=$ the rate of maximum biogas production, (L/kg.day)

$\lambda=$ the time of lag phase, day

$\mathrm{t}=$ the time of cumulative biogas production, day

$\mathrm{e} \quad=$ Euler number $(\mathrm{e}=2.71828 \ldots)$

By using non-linear regression method, the data obtained from experiments using biodigester kinetic constants can be obtained as presented in Table 1 .

The value of $\mathrm{Rm}$ is the lowest value on palm oil fruit bunch in solid state condition and $\mathrm{C} / \mathrm{N} 25$ with a value of $1.92 \mathrm{ml} / \mathrm{gr}$ TS day. It can be referred that the processes of biogas production in this variable proceed slowly. While the highest Rm value figures on smooth palm oil fruit bunch in liquid state condition and $\mathrm{C} / \mathrm{N} 30$ with a value $5.73 \mathrm{ml} / \mathrm{gr}$ TS day. Thus, with that size, the addition of microbial consortium, biodigester condition and $\mathrm{C} / \mathrm{N}$ affect the biogas production process [46]. 
Table 1. The Kinetics data of biogas production according the calculation of Gompretz equation

\begin{tabular}{|c|c|c|c|}
\hline Variable & $\begin{array}{c}\mathrm{Rm}(\mathrm{ml} / \mathrm{g} \\
\text { TS.day) }\end{array}$ & $\begin{array}{c}\mathbf{P} \\
(\mathrm{ml} / \mathrm{g} \\
\mathrm{TS})\end{array}$ & $\begin{array}{c}\lambda \\
\text { (day) }\end{array}$ \\
\hline $\begin{array}{l}\text { rough }+ \text { liquid state }+ \\
\mathrm{C} / \mathrm{N} 25\end{array}$ & 4.43 & 104.40 & 26 \\
\hline $\begin{array}{l}\text { rough }+ \text { liquid state }+ \\
\mathrm{C} / \mathrm{N} 30\end{array}$ & 5.23 & 114.08 & 12 \\
\hline $\begin{array}{l}\text { rough }+ \text { solid state }+ \\
\mathrm{C} / \mathrm{N} 25\end{array}$ & 5.06 & 123.25 & 16 \\
\hline $\begin{array}{l}\text { rough }+ \text { solid state }+ \\
\mathrm{C} / \mathrm{N} 30\end{array}$ & 5.09 & 120.47 & 14 \\
\hline $\begin{array}{l}\text { rough }+ \text { microbial } \\
\text { consortium }+ \text { liquid } \\
\text { state }+ \text { C/N } 25\end{array}$ & 8.63 & 145.49 & 2 \\
\hline $\begin{array}{l}\text { rough }+ \\
\text { microbial } \\
\text { consortium } \\
+ \text { liquid state }+ \text { C/N } 30\end{array}$ & 6.06 & 126.51 & 12 \\
\hline $\begin{array}{l}\text { rough }+ \\
\text { microbial } \\
\text { consortium } \\
+ \text { solid state + C/N 25 }\end{array}$ & 4.82 & 112.70 & 12 \\
\hline $\begin{array}{l}\text { rough }+ \\
\text { microbial } \\
\text { consortium } \\
+ \text { solid state }+ \text { C/N } 30\end{array}$ & 4.41 & 98.46 & 6 \\
\hline $\begin{array}{l}\text { smooth + liquid state }+ \\
\text { C/N } 25\end{array}$ & 4.82 & 120.29 & 10 \\
\hline $\begin{array}{l}\text { smooth + liquid state }+ \\
\text { C/N } 30\end{array}$ & 4.94 & 131.18 & 6 \\
\hline $\begin{array}{l}\text { smooth }+ \text { solid state }+ \\
\text { C/N } 25\end{array}$ & 6.51 & 154.12 & 4 \\
\hline $\begin{array}{l}\text { smooth }+ \text { solid state }+ \\
\text { C/N } 30\end{array}$ & 4.99 & 120.33 & 14 \\
\hline $\begin{array}{l}\text { smooth }+ \\
\text { microbial } \\
\text { consortium } \\
+ \text { liquid state }+ \text { C/N } 25\end{array}$ & 7.71 & 161.13 & 4 \\
\hline $\begin{array}{l}\text { smooth }+ \\
\text { microbial } \\
\text { consortium } \\
+ \text { liquid state }+ \text { C/N } 30\end{array}$ & 4.65 & 113.63 & 10 \\
\hline $\begin{array}{l}\text { smooth }+ \\
\text { microbial } \\
\text { consortium } \\
+ \text { solid state }+ \text { C/N } 25\end{array}$ & 4.29 & 91.54 & 20 \\
\hline
\end{tabular}

The value of $\mathrm{P}$ from each variable has different value, starting from 38.30 until $58.28 \mathrm{ml} / \mathrm{gr}$ TS where the lowest volume of smooth palm oil fruit bunch with the addition of microbial consortium, in solid state condition, and C/N 25, and the highest volume contained on palm oil fruit bunch, in solid state condition and $\mathrm{C} / \mathrm{N}$ 30. It can be indicated that the presence of a physical pretreatment (milling), biology (the addition of EM-4) and chemical (addition of $\mathrm{NaOH}$ ) affect the amount of biogas production in each variable. The highest $\lambda$ value almost consists on each variable, while biogas production started from the second day. The lowest $\lambda$ value contained in rough palm oil fruit bunch, solid state condition, C/N 30 and on rough palm oil fruit bunch, liquid state condition, $\mathrm{C} / \mathrm{N} 30$, where the biogas is formed at day 264. It proves that size does not significantly influence the time of biogas production.

The biogas production kinetics modified Gompertz equation and found that the data predicted by the model are quite close to the experimental data. It also indicates the presence of a physical pretreatment (milling), biology (the addition of microbial consortium), and chemical (addition of $\mathrm{NaOH}$ ) maximum biogas production (U) and biogas production potential (A) of all improved lignocellulose biomass. Modified Gompertz equation also describes the cumulative gas production as a function of residence time [47]. $\lambda$ value has an influence on the start time of the first biogas when it is formed or increased [48] Some raw materials originating from livestock manure has a longer adaptation time. In this study, using of cow dung and thus require a longer adaptation period, but the organic matter can decompose perfect views of cumulative production fairly competitive with a variety of other substrates such as in Table 4.2 [49]. By doing so, palm oil fruit bunch combined with cow dung can be used as feedstock for biogas production, but takes time to form a fairly long compared to some raw materials from previous studies.

\section{Conclusion}

Physic pretreatment (size reduction) and biological pretreatment (the addition of microbial consortium) in palm oil fruit bunch can increase surface area, decrease crystallinity and degree of polymerization for cellulose. Microorganism can be used for lignocellulosepretreatment and increase enzymatic hydrolysis. Biogas production is higher for solid state condition instead of liquid state because of the nutrient content per volume is more concentrated. $\mathrm{C} / \mathrm{N}$ from organic matters determined microbial activity and biogas production. The optimum production of biogas refers to $\mathrm{C} / \mathrm{N} 30$ because the most optimum substrate contains $\mathrm{C} / \mathrm{N}$ ranges from 20 to 30 .

Authors thank to Department of Chemical Engineering, Diponegoro University for all facilities to do this research.

\section{References}

1. S. Said. Indonesian Energy Outlook 2014. National Energy Board-Indonesian National Energy Council (2014)

2. S. Fletcher, Oil and Gas Journal (2013)

3. P.A. Ukpai. and M.N. Nnabuchi, Advances in Applied Science Research, 3, 3,1864-1869 (2012)

4. . Basker, S. Basker, R.S. Dhillon. Biomass Conversion: The Interface of Biotechnology. Chemistry and Materials Science, Springer (2012) 
5. A. Demirbas, Energy Conversion and Management 49, 2106-2116 (2008)

6. J. Twidell and T. Weir. Renewable Energy Resources Third Edition. New York: Routledge (2015)

7. D. Waskito. Biogas Power Plant Analysis from Cow Dung Manure in Cow Farm. Thesis of Faculty of Engineering, University of Indonesia (2011)

8. X. Chen, R. Romano, R. Zhang, International Journal of Agricultural and Biological Engineering, 4, 51-62 (2010)

9. T. Prasetyo, S. Sumardiono, H.A.A. Aji, A.Y. Pratama, Advanced Science Letters 23, 6, 58105814 (2017)

10. K. Zieminski and F. Magdalena, African Journal of Biotechnology 11, 18, 4127-4139 (2012)

11. K. Doelle and F. Oliveira, Journal Food Process Technol,6, 2157-7110 (2015)

12. S. Sumardiono, A.B. Riyanta, H.H.A. Matin, T.D. Kusworo, B. Jos, Budiyono, MATEC Web of Conferences, 101, 02014 (2017)

13. Batstone, D.J., J. Keller, I. Angelidaki, S.V. Kalyuzhnyi, S.G. Pavlostathis, A. Rozzi, W.T.M. Sanders, H. Siegrist and V.A. Vavilin, Water Sci. Technol. 45, 557-565 (2002)

14. Esposito, G., L. Frunzo, A. Panico and F. Pirozzi, J. Process Biochem 46, 557-565 (2011)

15. Budiyono, I. Syaichurrozi, S. Sumardiono, Journal of Applied Sciences, Eng. And Technol. 7, 13, 2798-2805 (2014)

16. S. Sumardiono, Budiyono, D.T. Mardiani. AIP Conference Proceedings 1699, 050018 (2016)

17. Budiyono, I. Syaichurrozi, S. Sumardiono, World Applied Sciences Journal 26, 11, 1464-1472 (2013)

18. Budiyono, I. Syaichurrozi, S. Sumardiono, International Journal of Engineering, Tramsactions B: Applications 27, 2, 177-184 (2014)

19. D. Brown, J. Shi, Y. Li. Comparison of solid-state to liquid anaerobic digestion of lignocellulosic feedstocks for biogas production. US National Library of Medicine National Institutes of Health (2010).

20. I. Mara, Engineering Dynamic, Mechanical Engineering 2, 1 (2010)

21. B. Rahman. Biogas, Sumber Energi Alternatif. Lembaga Ilmu Pengetahuan Indonesia (2005)

22. T. Hoerz, K. Pedro, B. Klingler, C. Kellner, T. Wittur, F. V. Klopotek, A. Krieg, H. Euler. Biogas Digest,I. Information and Advisory Service on Appropriate Technology (ISAT) Germany (2008)

23. F. Streffer, JSM Biotechnol Bioeng 2, 1, 1023 (2014)

24. A. Teghamar. Chalmers University of Technology (2013)
25. M.M. Kabir, M. Shafiei, H. Zilouei, I.S. Horvarth, K. Karim, Bioresource Technology, XXX, 32 (2014)

26. M. Dekker. Wood and Cellulosic Chemistry. New York: Madison Avenue (1991)

27. P.F.H. Harmsen, W.J.J. Huijgen, L.M. Bermudez Lopez, R.R.C. Bakker, Food and Biobased Research Wageningen Netherlands (2010)

28. N. Mosier, C. Wyman, B. Dale, R. Elander, Y.Y. Lee, M. Holtzapple, and M. Ladisch, Bioresour. Technol. 96, 673-686 (2005)

29. M. J. Taherzadeh, K. Karimi, International Journal of Molecular Sci. 9, 1621-1651 (2008)

30. A.T.W.M. Hendriks and G. Zeeman, Bioresource Technology 100, 10-18 (2009)

31. P. Kumar, D.M. Barrett, M.J. Delwiche and P. Stroeve, Ind. Eng. Chem. Res. 30, No. 20, 40-58 (2009)

32. E. Bruni. Improved Anaerobic Digestion of Energy Crops and Agricultural Residues. PhD Thesis. Department of Environmental Engineering, Technical University of Denmark (2010)

33. Y. Li, S. Park, J. Zhu, Renew Sustain Energy 15,821-826(2011)

34. Y. Zheng, J. Zhao, F. Xu, Y. Li, Progress in Energy and Combustion Science 42, 35-53 (2014)

35. Budiyono, A. Wicaksono, A. Rahmawan, H.H.A. Matin, L.G. K. Wardani, T.D. Kusworo, S. Sumardiono, MATEC Web of Conference 101, 02011 (2017)

36. M. Taniguchi, H. Suzuki, D. Watanabe, K. Sakai, K. Hoshino, and T. Tanaka, J. Biosci. Bioeng. 100, 6, 6737-643 2005)

37. M. Kurakake, N. Ide, T. Komaki, Current Microbiology 54, 424-428 (2007)

38. K.M. Kangle, S.V. Kore, V.S. Kore, G.S. Kulkarni, Universal Journal of Environmental Research and Technology 2, 4, 210-219 (2012)

39. M. Yani dan A.A. Darwis. Biogas Technology Book. Bogor Institute of Agriculture (1990)

40. Y. Lin, D. Wang, L. Wang, Waste Manag. 28,800810 (2010)

41. D. Deublein, A. Steinhauser. Biogas from Waste and Renewable Resource. Wiley-VCH Verlag GmbH \& Co. KGaA, Weinheim (2008)

42. D.O. Indriani, L.N. Syamsudin, L. N., F.H. Sriherfyna, A.K. Wardani, Food and Agroindustry Journal 3, 1405-1411 (2015)

43. S. Merlina, A.D. Lubis, Y. Retnani. Perubahan Kandungan Nutrient Wheat Bran yang Difermentasi Menggunakan Level Starter Aspergillus niger yang Berbeda. Thesis of Institut Pertanian Bogor (2012)

44. A. Nopharatana, P.C. Pullammanappalli, W.P. Clarke, Waste Management 27,595-603 (2007) 
45. I. Syaichurrozi, Budiyono, S. Sumardiono, Bioresource Technology 149, 390-397 (2013)

46. A.N. Ikrimah, A. Pramianshar. Innovation in Biogas Technology through Anaerobic Digestion from Fish Processing Waste as A Renewable Energy Source. Thesis of Chemical Engineering Department, Diponegoro University, Semarang (2014)

47. M.D. Ghatak, P. Mahanta, International Journal of Engineering and Advanced Technology (IJEAT) 3, 2249 - 8958 (2014)

48. Budiyono, I. N. Widiyasa, S. Johari, Sunarso. International Journal of chemical and biological Engineering 3, 1, 39-44 (2010)

49. Budiyono, I.N. Widiasa, and S. Sumardiono, Waste Technol. 1, 1, 1-5 (2013) 